\title{
To what extent did the Bible translations into indigenous languages of Southern Africa produced since 1966 reflect the purpose of providing meaning-based translations?
}

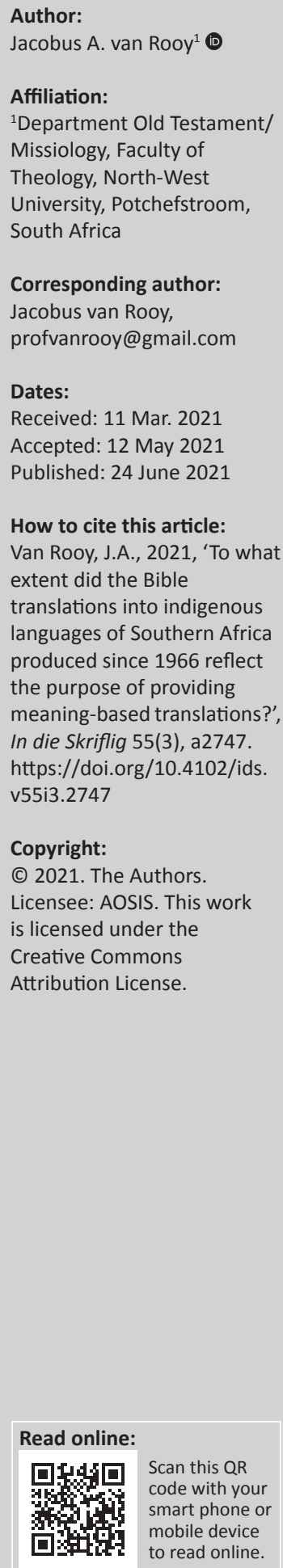

Since the Bible was intended by die first authors to be understood by all believers, it is important to have an idea of the extent to which different translations succeeded in this respect. The author noticed that some of the latest Bible translations in Southern Africa are inconsistent with respect to the translation policies they followed, sometimes translating according to the meaning, and sometimes literally, distorting the meaning. He then selected a number of theologically important terms from the Bible for the purpose of comparing the way those were translated in the different translations.

Contribution: It was found that some of these translations, particularly the 1983 Afrikaans translation, the Venda translation of 1998, and the Xhosa translation of 1996, consistently translated according to the meaning, and two of them, to wit the latest Southern Ndebele and Zulu translations, very literal, and the rest somewhere in between these methods, sometimes translating quite literally, and sometimes more meaningfully, but generally not consistent.

Keywords: translation; meaningful; idiomatic; literal; Southern African translations.

\section{Delimitation}

With 'the Southern African Indigenous Languages' is meant Zimbabwean Ndebele (1978, referred to as NdeZ), Afrikaans (1983, referred to as Afr83), Northern Sotho (for which the term Pedi is used - 1992), Southern Sotho (referred to as Sotho - 1996), Xitsonga (1989, referred to as Tsonga), Swati (1996, referred to as Swati), Xhosa (1996, referred to as Xhosa), Venda (1998, referred to as Ve98), Southern Ndebele (2012, referred to as NdeS), and the most recent of all, the recently published Zulu translation (referred to as Zulu20). ${ }^{1}$ The 2020 Afrikaans translation is not discussed, since from the start it was intended to be a 'direct' rather than a meaning-based translation, the purpose being to provide an additional translation in Afrikaans in which the idiom and flavour of the original languages are preserved.

The date 1967 is taken as point of reference, being a watershed year for Bible translation in Southern Africa. In July 1967 a 3 week workshop for translators was organised by the Bible Society of South Africa. It was held at the University of the North and attended by the translators working on the translations mentioned above, excluding those who provided the final manuscripts of NdeS and Zulu20. Almost all the translations produced before 1967 were not based on any scientific principle, but on the assumption that a faithful translation means a translation as near as possible to the idiom, word order and vocabulary of the Hebrew or Greek original.

At that workshop in July 1967 the translators were trained to produce meaning-based translations. The main teacher was Dr Eugene Nida, and the theory, ideas and methods delineated at that workshop were published by Dr Nida (1964) in his book, Towards a science of translation.Translations produced after that date under the auspices of the Bible Society of South Africa were intended to follow the principle that the translations should reflect as closely as possible the meaning as perceived by the original readers. The Zulu20 was initially intended to be meaning-based, and translated accordingly, but after the retirement of myself as project coordinator it was revised with the idea to make it 'more accurate', which in this case meant 'more literal'. When reading 
NdeS, one gets the impression that it was not intended to be meaning-based. I include it in this comparison for the sake of completeness.

Space and time leave us no opportunity to discuss the relative merits of these different approaches. The purpose of this paper is not to provide a summary of the merits or demerits of a 'dynamic equivalent' or 'functional equivalent' translation, but rather to limit ourselves to a comparison on the basis of the degree to which each translation reflects the principle of rendering the meaning of a text. My own viewpoint is that the Bible is revelation from God about his relations with humankind in the course of history, and as such was intended, unless clearly stated in the text itself, to be understood by all believers.

\section{Types of distortion of the meaning in translation}

\section{Meaningless translation (zero meaning communicated)}

\section{Time, distance, content measures}

Examples of this can be found in most of the older translations, and even in the new, 2020, isiZulu translation.

Examples of measures of distance (length, breadth etc.) are found in Genesis 6:15,16; 1 Samuel 17:4. Zulu20 transliterates 'cubits' as 'amakhubithi'. All other translations use measures of distance which are familiar to modern readers (metres or decimals of it).

\section{Stadia Luke 24:13; John 6:19; 11:18; Revelation 14:20;} 21:16

Afrikaans uses kilometres everywhere. Xhosa has kilometres, with footnotes explaining what the original 'stadia' means in all cases. Swati has kilometres in the Gospels, but 'amastadiu' in Revelation, with no footnotes or explanation; probably because the distances in Revelation are obviously symbolic. Pedi has kilometres everywhere, in Revelation rendering the stadia in a more or less equal distance in kilometres, but in the process changing the symbolical distances to actual ones. Sotho did exactly the same as Pedi in the respective passages.

Ve98 rendered it 'kilometres' everywhere, not changing the numbers in Revelation, same as Afr83. Tsonga rendered it with $\mathrm{km}$ in the historical passages, and $300 \mathrm{~km}$ in Revelation $14: 20$, but with 'mpimo wa "tistadia" ta 12,000' ('distance of 12000 stadia') in Revelation 21, with no explanation either in a footnote or in the Wordlist. NdeZ used kilometre in all cases, like Pedi and Sotho. NdeS has kilometres in Revelation 20, but miles in Revelation 14. Zulu20 transliterates all distances, never using terms meaningful to the average reader.

Summarising, it seems that apart from Ve98 and Afr83, the translations are rather inconsistent, and Zulu20 consistently meaningless.

\section{Content or weight}

Examples of these are omer, ephah, kab.

Omer, ephah, hin.

Judges 6:19

Afr83: kilogram; NdeS: isithjuthjana ('a small bunch'); Xhosa: kilogram; Swati: kilogram; Pedi: kilogram; Sotho: kilogram; Ve98: kilogram: Tsonga: a basketful; NdeZ: an ephah basket full; Zulu20: efa.

\section{Numbers 5:15 and 28:5}

Afr83: kilogram; NdeS: 'ithungana' ('a small vessel'); Xhosa: kilogram; Swati: the first one litre, the second kilogram; Pedi: kilogram; Sotho: 'kilo'; Venda: kilogram; Tsonga: 'xintewana xin'we' ('one small winnowing basket'), with a footnote; NdeZ: 'ihefa' (ephah); Zulu20: 'efa'.

kab. 2 Kings 6:25 (a quarter of a kab is approximately $1 \mathrm{~kg}$ ).

Afr83: gram; Xhosa: gram; Swati: enough pigeon dung to fill one's hand; Pedi: gram; Sotho: gram; Ve20: gram; Tsonga: 'enough to fill one's hand'; NdeZ: 'igajana lombhida' (a small lump); Zulu20: 'okwesine kwesigaxa' (a quarter of a lump) the only effort in this translation to translate rather than transcribe. One would like to learn the reason for this inconsistency.

In summary we can conclude that in rendering terms for weights and measures, all translations, except Zulu20, translated the measures in terms familiar to the readers. The latter consistently preferred renderings foreign to Zulu readers.

\section{Factually incorrect translation}

Indicating time: Matthew 27:45; Mark 15:25,33,34; Luke 23:44; John 19:14; 1:40; 4:6; Acts 2:15; 10:3.

Afr83 everywhere uses present day terms, as do all the others, with the exception of Zulu20, which consistently renders times of the day in such a way that the average reader cannot but misinterpret it. According to this version of Matthew 27, Mark 15, Luke 23 and John 19, the crucifixion took place at 03:00 and the darkening of the sun from 06:00 to 09:00.

The gospels agree that the crucifixion of Jesus took place at 09:00, and darkness fell over the land from 12:00 to 15:00, when He expired. At Pentecost the Holy Spirit was poured onto the disciples at 09:00.

A rather glaring example of a factually inaccurate translation, probably due to carelessness, is found in Tsonga, 1 John 5:14: 'loko hi kombela xilo xihi na xihi hi laha hi rhandzaka hakona' (if we ask anything whatever we want) - instead of 'if we ask anything which is according to Gods will'. 


\section{'Poor in spirit'}

An interesting example of this kind of misleading translation can be found in the various versions of Matthew 5:3, the wellknown 'Blessed are the poor in spirit'. Very few readers understand the meaning of a literal translation of this verse. The most frequent interpretation among layman of 'poor in spirit' is mentally retarded'. I have heard it more than once, from my teacher in std 3, 81 years ago, and later found it in the versification of the Beatitudes by the celebrated theologian J.D. Du Toit (Totius), where it is interpreted as follows:

\section{Salig dié wat arm van gees is \\ en van God hul wysheid leer. \\ (Blessed the spiritually poor \\ who learn their wisdom from God).}

The implication of this translation is that 'poor in spirit' means 'ignorant' or 'lacking wisdom'.

NdeS, NdeZ, Swati, Sotho, Tsonga and Zulu20 translate literally. Afrikaans, Ven98 and Xhosa translate meaningfully, or at least venture to do it.

\section{'In Christ'}

This is also an expression that remains obscure if translated literally. Let us look at the different translations in Galatians 3:28.

Good News Bible (GNB) 'you are all one in union with Christ Jesus'; Afr83: 'in Christus Jesus is hulle almal een'; NdeS: 'kuKrestu' (at Christ); Xhosa: 'ngokumanywa noJesu Krestu' (by being united with Jesus Christ); Swati: 'kuKhristu Jesu' (to/from Christ); Pedi: 'ka go dumela go Kriste' (by believing at Christ); Sotho: 'ka Kreste (by means of Christ); Ve98: 'nge na vha vhathihi na Khristo Yesu' (because you became one with Christ Jesus); Tsonga: 'eka Kriste', (at Christ); NdeZ: 'limunye kuKristu Jesu' (you are one at Christ Jesus); Zulu20: 'nimunye kuKhristu uJesu' (you are one at Christ Jesus). I seriously question the use of the locative $\mathrm{ku}^{-}, \mathrm{go}-$, eka- and related forms in Bantu languages in this context. According to me it says nothing in this context, as in kukhreste or kuye. It normally indicates motion towards or from, but I have never heard it used outside the Bible with the meaning 'in'. The Xhosa and Ve98 are the only versions which translate the meaning clearly: 'in union with Christ'.

\section{Misleading translation because of disregard of context}

The referential (precise) meaning of a word is determined by the context in which it occurs. By way of illustration, let us have a look at the meanings of the term Hebrew bâsâr and Greek sarx, always translated 'flesh' in the King James Version, 'vlees' in the Afrikaans 1933/53 edition, and 'nama/ inyama' or the corresponding term for 'meat' in almost all the older versions in Bantu languages. The problem becomes more acute since in Bantu languages 'flesh' and 'meat' are the same term, nama, inyama and related terms, according to the language in question.

\section{Bâsâr/sarks}

Looking through the concordance, I was surprised to note that the Hebrew or Greek term is used to refer to altogether 15 different concepts or nuances of concepts in different contexts. Having checked the Hebrew concordance of Wigram (1980), I also consulted the Greek concordance of Westcott and Hort as revised by Moulton and Geden (1963). Here follows the list of different referential meanings of bâsâr/sarx:

Human flesh: Examples: Genesis 2:21c; Jeremiah 19:9; Zechariah 14:12; Revelation 19:18.

In Isaiah 9:19 the Hebrew may be vowelised in different ways (GNB 'They eat the flesh of their own children', vowelising zar'o) but also possible is Afr20 'verteer hulle eie krag', (vowelising $z^{e} r o^{\prime} o$, 'the flesh of his own right arm'). All the African languages which accept the last-mentioned interpretation will obviously here use the term for 'meat'. Most translations opted for the first option, not following the massoretic vocalisation. Then 'human flesh' would be the acceptable interpretation.

Meat for consumption (Gn 9:4; Ezech 11:3): In all cases of a similar context the choice for a literal translation (nama, inyama etc) is so obvious that there is no need for a comparison.

Unity of spouses: Genesis 2:24; Matthew 19:5 (quoting Gn 2:24) GNB: 'they become one'; Afr83: 'hulle twee sal een wees'; NdeS: 'bese babe nyamanye' (they will then be one flesh); Xhosa (Genesis): 'baze babe mntu munye' (they will then become one person), Matthew: 'baze bamanyane' (they will then be united); Swati: 'bese babe nyamanye' (they will then be one flesh); Pedi: 'bobedi bja bona ya ba mmele o tee' (they will both be one body; idiom seems to be influenced by English, especially when compared with the Sotho: 'babedi bao ba tla fetoha ntho e le nngwe' - those two will change into one); Ve98: Genesis: 'vha vha nama nthihi'; Matthew: 'vhuvhili havho vha vha nama nthihi' (the two of them will be one flesh; the same objection as in Pedi, but note Ve98, Eph 5:31); Tsonga: 'vha endla nyama yin'we' (and make one flesh), and in Matthew 19: 'va ta va nyama yin'we ntsena' (they will be only one flesh - not consistent); NdeZ: 'bazakuba nyamanye' (they will be one flesh - same in Matthew); Zulu20: 'bayakuba nyamanye' (they will be one flesh). It still seems to me that 'one body' (The Jerusalem Bible) is a better rendering than 'one flesh'.

Human body: Job 19:26 (GNB 'while still in this body I will see God'). Afr83: 'sal ek nog lewe en God sien'; NdeS (in this version part of vs. 27): 'Iye, a bonwe ngimi ngenyama' (Yes, he will be seen by me by the flesh); Xhosa: 'noko uThixo yena ndiyakumbona ndidlavuke ndinjalo' (yet I shall see God, afflicted as I am); Swati: 'noko emtimbeni wami ngiyawumbona uNkulunkulu' (nevertheless I shall see God while in my body); Pedi: 'ke tla bona Modimo ke sa 
phela' (I shall see God while I am still alive); Sotho: 'Modimo ke tla mmona ke se mmeleng wona' (God I shall see while I'm still in this body); Ve98: 'Ndi do vhona Mudzimu ndí kha muvhili wonouno' (I shall see God while in this same body); Tsonga: 'ndzi ha ta va munhu, ndzi vona Xikwembu' (I shall still be a real person, seeing God); NdeZ: (This seems to be a translation of another than the Massoretic text); Zulu20 'ngingokhululekile emzimbeni' (set free in my body; meaning unclear).

Weak, mortal creature, mere human: Genesis 6:3 (GNB 'They are mortal'); Afr83, Xhosa, Pedi, Ve83 and Tsonga translated according to the meaning, the other five literally.

Jeremiah 17:5. Here none, not even NdeS or Zulu20 translated literally.

Matthew 16:17 (sarx kai haima, 'flesh and blood', which means 'a mortal human'). Only NdeZ and Zulu20 translated literally.

John 6:63 GNB: 'human power is of no use at all'; Translating sarks here with 'meat' is a very disputable option, producing a quite ridiculous result, but only 4 of the 10 translations translated this expression according to the meaning. Yet in Galatians 1:16 the very same term is translated meaningfully by 9 out of 10 .

Physical body with its limitations in contrast with spirit: Isaiah 31:3 (GNB 'their horses are not supernatural'). Afr83: 'Hulle perde is maar net perde' (Their horses are merely horses). Apart from Swati ('Their horses are just meat, not spirit'), all translations are acceptable.

2 Corinthians 7:5. Afr83: 'het ons geen rus of duurte gehad nie'. No literal translation here.

Truly human: John 1:14. Here the two isiNdebele translations are the only ones which offer a literal translation ('meat'), even Zulu20 translated according to the meaning.

Human body (of the resurrected Christ): Luke 24:39 ('A spirit does not have flesh and bones'). Here a literal translation is obviously the correct one.

Humankind, human race: Genesis 6:12, 13 GNB: 'the whole human race ... all the people'. No literal translation here, neither in Is 66:24, although the idiom of several translations for translating the idea of 'to be something for/to someone' (as in, 'this is an abomination to Yahve') is questionable. Some translations rightly preferred using the verb 'to disgust' here ('Their deeds disgusted Yahve').

Joel 2:28: (GNB 'I will pour out my Spirit on everyone'). None could imagine the Holy Spirit being poured onto meat. This is laudable, but why translate according to the meaning here, and elsewhere so literally? It is an indication of the quality of translations, that Zulu20 is the only version that has the Holy Spirit poured onto meat in Acts 2:17, where this verse is quoted. One must admit that in a footnote the possibility is mentioned that he might be poured onto people.

Physical: Romans 2:28 (hê... en sarki peritomê). NdeS, Xhosa, Sotho and Zulu20 translated 'flesh', most of the rest opted for the more idiomatic 'body'. It is interesting to note that Pedi (Northern Sotho) usually shows more awareness of natural idiom than its close relative (Southern) Sotho.

Romans 4:1 Afr83: 'ons stamvader' (our common ancestor). Again NdeS, NdeZ and Zulu20 translate literally and awkwardly ('our ancestor according to the flesh'. Bantu idiom would prefer 'of the same blood'.

Romans 9:3 'Afr83: my eie volksgenote' (author's own compatriots). As is to be expected, literal translation from NdeS ('according to the flesh'), and in this case also NdeZ.

Human motivation/perspective/norm: 2 Corinthians 11:18 GNB: 'for merely human reasons'. Here too, Zulu20 is the only version which comes up with 'meat/flesh'.

John 8:15 (Greek 'kata ton sarka'); GNB 'You make judgements in a purely human way'. Sotho, NdeZ and Zulu20 translates literally, NdeS translates here according to the meaning.

2 Corinthians 5:16 'by human standards'. In this case NdeS and Zulu20 are the only versions which ignore the context.

Corinthians 10:2 GNB: 'from worldly motives'. NdeS and Zulu20 consistently offers literal translations, all the others translate according to the meaning.

1 Corinthians 1:26 Afr83: 'volgens die opvatting van mense'. Here Zulu20 is the only literal translation.

It is clear that even those translations which often produce a meaning-based rather than a literal meaning, are often inconsistent.

Sinful human nature, hostile to God: Paul, more than anyone else, uses the term in this sense, eg. in.

Romans 7:5, 18, 25: GNB translates 'human nature' in all three verses, NdeS renders literally, and, uncharacteristically, also Pedi. NdeZ has 'flesh' only in versus 18, and Zulu20 only in versus 5, elsewhere translating sarks as 'body'. However, translating sarks as 'body' in this context, is not acceptable, since it expresses the unbiblical, gnostic view that $\sin$ is primarily or exclusively a matter of the body.

Romans 8:3, 4, 5, 6, 7, 8, 9, 12, 13 GNB: 'human nature' in all cases; Afr83: 'sondige natuur' everywhere, and 13:14: 'sondige begeertes'. NdeZ: 'isimo samuntu' in versus 3 (human nature), everywhere else 'ngokwabantu' (in the way of humans), but it translates '-hamba' (walk) instead of '-phila' (live); Zulu20: 'inyama yemvelo' - twice) 
(the flesh of nature), 'ukuhamba ngokwenyama' (to walk according to the flesh), 'okwenyama' (the way of the flesh), 'ezintweni zenyama' (to the things of the flesh - twice), 'imvelo' (nature), 'inyama' (flesh), and in versus 13 'umzimba' (body). There is no indication why all this inconsistency, and in versus 13 it again turns out that sin is particularly a thing of the body. For some reason Pedi again deviates from its usual meaningful translations to a literal one, while Sotho in this case translates according to the context.

Any living creature: Genesis 7:15,21 (GNB 'living being') This is one of the few places where none of the versions in question translates literally.

Male reproductive organ: Genesis 17:11 (GNB 'every male ... must be circumcised', Afr83 'julle moet besny word aan die voorhuid'). The majority of translations do not deem it necessary to make explicit the foreskin, since it is implied in the verb. It does not really make any difference to the meaning. This seems to be one of the very few cases where even the most literal translations do not translate the noun with 'flesh'or 'meat'.

A tender (obedient) heart, not stubborn: Ezech 11:19 KJV 'take away the stony heart and give them a heart of flesh'. In this context, where the heart of stone is compared with a heart of flesh, translating 'flesh' seems acceptable, although a rendering like that of NdeS (a soft heart) or 'an obedient heart' may be acceptable.

\section{Literal translation, sometimes motivated (as in Hosea 4:6) by the (secular) interests of the speakers or theological prejudice, tradition or ignorance}

4.1 A poignant example of this is the way the Hebrew term yada'/da'at or the Greek gignooskoo/gnoosis/prognoosis (know, knowledge, foreknowledge) is translated. The Greek in the New Testament usually expresses not the classical Greek meaning of the term, but rather the meaning of the Hebrew yada'/da'at. In Hebrew, the verb indeed sometimes expresses no more than cognitive knowledge, as in Genesis 48:29, where Jacob answers Joseph, 'I know, my son, I know' (i.e. that Manasseh is the elder son). However, more often, particularly when a person or God is the object of the verb, it implies not a mere cognitive knowledge, but an intimate relationship between the subject and the object of the verb. To know God is to be in a right relationship with him, with characteristics of love, trust, respect, and open communication (see parallels to faithfulness and steadfast love in Hs 4:1, 6:6; believing in Is 43:10). God himself is the focus, in a personal relationship growing out of a living encounter with God.

\section{A few examples:}

- Galatians 4:9: GNB: 'But now that you know God - or, I should say, now that God knows you - how is it that you want to turn back to those weak and pitiful ruling spirits?'
- John 17:3: GNB: 'And eternal life means knowing you, the only true God, and Jesus Christ, whom you sent'.

1 Peter 1:2 (prognosis, foreknowledge, which actually means 'election'), 1:20 (proegnoosen) GNB: 'You were chosen according to the purpose of God the Father... He (Christ) had been chosen by God before the creation of the world'. In verse 2 only the NdeS, NdeZ and Zulu20 translated with a term meaning 'knowledge', the rest translated according to the context, showing theological and exegetical awareness. In verse 20 Zulu20 is the only version which produced a literal translation.

Hosea 4:6: GNB: 'My people are doomed because they do not acknowledge me'; Afr83: 'My volk gaan onder omdat hulle nie aan My toegewy is nie' (My people perish because they are not devoted to me). NdeS, Sotho, NdeZ and Zulu20 translated literally ('My people perish for lack of knowledge'). Swati and Tsonga, which usually show more exegetical awareness, also failed to grasp the true meaning of $d a^{\prime} a t$ in this case.

The considerations about and implications of this translation need some more discussion.

When Hosea 4:6 was discussed at the meeting of the Review Committee of Zulu20, they had before them a translation which reflected the meaning of da'ath as 'intimate fellowship with God', much richer that mere cognitive knowledge. However, in all the older translations of which we know, it had been translated lack of knowledge', which anyone not familiar with the context would interpret as 'lack of cognitive knowledge'. The chairman said: 'This is a well-known text, and we should leave it the way it used to be'. This was accepted without further discussion. I am quite sure that one of the reasons this text is well-known, is precisely the widespread secular interpretation of it: 'We should have more and better schools and teachers, more funds and bursaries for university students, because our people perish for lack of knowledge'. This perception was confirmed by an experience I had a few months after that Review Committee meeting. I was attending a lecture about Pedi folklore at the University of the North. At a discussion of a publication about Pedi folktales, a student observed: 'Somewhere in the Bible it is said that "my people perish for lack of knowledge", and that is true; our people do not know these cultural treasures anymore'. That perception is the reason why it is particularly important to translate this verse - as we should when translating any portion of Scripture - with a thorough exegetical background, otherwise translators distort the Word of God in their labours. The meaning of Hosea 4:6 is that those who have no personal relationship with God, shall perish. It does not refer to the volume of knowledge one has, whether secular or spiritual. It is interesting to note that so few, if any, of the literal translations accommodate the definite article in hadda'at.

Amos 3:2 is another example of the same term with the same meaning: 'You alone I chose from among all the nations of the earth'. 


\section{(dikaiôoo/dikaioosis/dikaiosunê)}

In older translations these three terms are usually translated 'justify/justification/righteousness'.

In the Gospels the meaning focuses on doing God's will since God's will is the norm for what is right. 'Joseph was a righteous man' (Mt 1:19) means that he was a person who wanted to do right. Obviously, the right thing was doing God's will, usually as expressed in the Law of Moses.

Paul, brilliant student of rabbi Gamaliel that he was, often employs this family of terms to express the Hebrew idea of judging in someone's favour (see Kittel, Friedrich \& Bromiley [1964] under dike, dikaios etc.) The term tsadiq usually means 'righteous, doing God's will', and raša' usually expresses the idea of 'evil, godless'. However, the terms tsadiq/hitsdiq and raša'/hiršiya' were often used in ancient Hebrew for expressing the idea of 'innocent/ acquit' or 'judge in favour of', and, on the other hand, 'guilty' and 'condemn' or 'pronounce an unfavourable verdict' (as several times in Gn 18:25). A very clear example of this is Proverbs 15:17: 'Matsdiq raša' umaršiya' tsadiq, tho'avath Yahveh gam šeneyhem: 'Acquitting the guilty and condemning the innocent are equally abhorrent to Yahveh'. Just as clear is Deuteronomy 25:1.

The apostle Paul uses the verb dikaiôoo with the meaning it has in Deuteronomy25:1 and Proverbs 15:17, viz. 'to acquit', in the context of 'We are acquitted by faith', and not 'to be made good by faith', as is generally translated in African languages.

Taking Galatians 2:16 as an example, the results of the comparison are as follows:

Tsonga translated it as $k u$ endliwa la lulameke ('to be made righteous' in the sense of 'good, upright'); Sotho translated the verb as ho lokafatswa, which means the same as the Tsonga term. Pedi uses the same verb, go lokafatšwa, with the same meaning. Swati translates the phrase with sentiwa simukeleke kuNkulunkulu kutsi silungile ('we are made acceptable to God as being righteous'). Xhosa translates, UThixo usenza amalungisa ('God makes us righteous/puts us in order'). NdeS and Zulu20 also translate the same as NdeZ, silungisiswa ('we are thoroughly repaired'), Venda, Ri pfi vhavhuya ('We are called good persons'), NdeZ, silungisiswa ('we are thoroughly repaired', Afr83, 'ons is vrygespreek' ('we were acquitted').

Summing up, Afrikaans translated it correctly, Venda made an effort to translate the meaning, not quite successfully. The rest used a verb or noun to express the idea of 'being made good' or 'repaired'. Swati came nearer to the meaning, but all could just have translated it with the term meaning 'to be acquitted'.

\section{Inadequate clarity of the meaning}

Space and time do not allow us to discuss this aspect in detail. We only need sufficient examples for the purpose of comparing recent translations. We shall discuss just one type of trap into which translators may be caught, to wit the describing genitive (genetious epexegeticus). Examples of this are the following: Gift/promise/fellowship of the Spirit'; 'Crown of righteousness'; 'tree of life' (Gn 3:22; Rv 22:2); 'words of life' (Jn 6:68); 'the God of peace' (Phlp 4:9); koinoonía tôิ uioû autôิ ('fellowship of his Son', 1 Cor 1:9); Elohee tsidqi ('God of my righteousness', Ps 4:1) There are many varieties of interpretation of the different functions of a genitive. We limit ourselves to two varieties, which is sufficient for evaluating the awareness of respective translators.

We shall look at only two of these, that is 'promise or fellowship or gift of the Spirit' and Elohee tsidqi.

'Promise of the Spirit' (Eph 1:13) can mean either 'something the Spirit promised us', which is the most obvious meaning when the context is not known or considered, or 'the Spirit who was promised to us', which is the actual meaning where it occurs in the New Testament.

'The fellowship of the Spirit' (2 Cor 13:13) can mean either 'the fellowship with the Spirit' (compare 1 Cor 1:9: 'fellowship of or with his Son), or the fellowship which the Spirit creates (between believers)'.

'Gift of the Spirit' (Acts 2:38) GNB 'God's gift, the Holy Spirit'; NdeS: 'isipho sikaMoya oCwengileko' (the gift of the Holy Spirit - which might mean a gift given by the Holy Spirit); Xhosa: 'isipho soMoya oyiNgcwele' (same as NdeS); Swati: 'nesipho lesinguMoya Longcwele' (the gift which is the Holy Spirit) - which leaves no room for ambiguity; Pedi: 'mpho ya Modimo, e lego Moya wo Mokgethwa' (the gift of God, which is the Holy Spirit); Sotho: 'mpho ya Moya o Halalelang' (same as NdeS); Ve98: 'ndi hone Mudzimu a tshi do mu nea Muya Mukhethwa' (then God will give him - that is everyone who believes and is baptised - the Holy Spirit); Tsonga: 'nyiko, wu nga Moya lowo Kwetsima' (the gift, which is the Holy Spirit); NdeZ: 'isiphiwo sikaMoya oNgcwele' (same as NdeS); Zulu20: 'isiphiwo sikaMoya oNgcwele' (same as NdeS). NdeS, Xhosa, Sotho, NdeZ and Zulu20 have an ambiguous translation, the others show awareness of the trap and avoided it.

\section{Elohee tsidqi (Ps 4:1 - literally 'God of my righteousness')}

NIV 'my righteous God' (which could be correct, cf. Psalms 51:11 - 'the Spirit of your holiness' which means 'your Holy Spirit'); Contemporary English Version (CEV): 'my God and protector'; GNB: 'God my defender'; Afr.83: 'God wat aan my reg verskaf' ('God who vindicates me'); NdeS: 'Zimu welungelo lami' (God of my right); Xhosa: 'Thixo, mlondolozi wamalungelo am!' (God, keeper of my rights); Swati: 'Nkulunkulu ukulunga kwami' (God my rightness); Pedi: 'Modimo, Moemedi wa ka' (God my defender); Sotho: 'mosireletsi wa ditokelo tsa ka' (protector of my rights); Ve98: 'Mudzimu Mulamuleli wanga' (God my defender); Tsonga 'mulweri wa tifanelo ta mina' (defender of my rights); NdeZ: 'Nkulunkulu wokulunga kwami' (God of my goodness); Zulu20: 'Nkulunkulu ongukulunga kwami' 
(God who is my goodness). The two Ndebele translations did not venture to translate according to the meaning, but left it to the imagination of the reader. The others offered acceptable meaningful translations, except that in Xhosa, Sotho and Tsonga the terms amalungelo, ditokelo and tifanelo for 'rights' are coined words which sound somewhat artificial in the Bible.

\section{Conclusion}

Here is the approximate statistic of the passages studied. Afrikaans produced no literal translation, Xhosa and Venda 3 each. Pedi 5, Tsonga 8, Sotho 12, the two Ndebele translations 17 each, and Zulu 20 in these passages produced 37 literal translations which distorted the meaning.

We may further conclude that academic excellence, knowledge of the target language and of Hebrew and Greek, do not guarantee a meaningful translation of the original. An essential requirement for a translator is thorough training in and understanding of Semantics and of the Science of Translation. According to my own experience, the South African Bible Society provides far too little training in the basics of these subjects to translators in its service. The result is that translators trained and employed by SIL, The Seed Company and The Word for the World, who usually have much less skill in theology and the biblical languages, still often come up with notably better and more understandable translations than the South African Bible Society with its academically excellent translators. That is my own experience while doing consulting work in at least 18 indigenous languages in Ethiopia, The Republic of the Kongo and Mozambique.

I would also recommend that all officials of the Bible Society who are in any way involved in planning and executing translation work, including all leaders who have to guide translations or have to make decisions about them, should have sufficient understanding of the principles of translation and requirements for translators. A Secretary for Translations should have expert knowledge of the Science of Translation, and one with little understanding of the subject, is likely to do more harm than good.

\section{Acknowledgements Competing interests}

The author declares that no competing interest exists.

\section{Author's contributions}

I declare that I am the sole author of this research article.

\section{Ethical considerations}

This article followed all ethical standards for research without direct contact with human or animal subjects.

\section{Funding information}

This research received no specific grant from any funding agency in the public, commercial, or not-for-profit sectors.

\section{Data availability}

The author confirms that the data supporting the findings of this study are available within the article.

\section{Disclaimer}

The views and opinions expressed in this article are those of the author and do not necessarily reflect the official policy or position of any affiliated agency of the author.

\section{References}

Kittel, G., Friedrich, G., Bromiley, G.W., 1964, The theological dictionary of the New Testament, 10 vols., Eerdmans, Grand Rapids, MI.

Moulton, W.F. \& Geden, A.S., 1963, A concordance to the Greek Testament, Clark, Edinburgh.

Nida, E.A., 1964, Towards a science of translation, Brill, Leiden.

Wigram, G.V., 1980, The Englishman's Hebrew and Chaldee concordance of the Old Testament, Baker, Grand Rapids, Baker, MI. 